\title{
Efficiency analysis of irrigation water demand institutions in Tunisia
}

\author{
Aymen Frija \\ Supervisor: Guido Van Huylenbroeck \\ Department of Agricultural Economics, Ghent University
}

Public defence: 1 July 2009

This $\mathrm{PhD}$ dissertation is studying the efficiency of irrigation water management institutions in Tunisia. Our general objective is to show that, not only do the existence and functioning of institutions for water demand management matter, but also their performance and effectiveness. According to this, we sought to prove that by designing and implementing high performing institutions, and by improving the functioning of existing ones, Tunisia can greatly improve the efficiency of agricultural water use. We assumed that the performance of irrigation institutions can be assessed using the "institutional decomposition" and "comparative institutional analysis" frameworks developed, among others, by Saleth and Dinar (1999, 2004).

Our approach for decomposing irrigation water institutions in Tunisia was based on the Institutional Decomposition and Analysis framework which distinguishes three main components of water institutions: components relating to constitutional choice rules: water laws; components relating to collective-choice rules: water policies; and components relating to operational rules: water administrations. In addition to this decomposition, in our analysis we also distinguished between the three layers of institutions according to the scheme proposed by Williamson (1996), who differentiated between the "governance framework", "governance structure", and "individual level". In this dissertation, we mainly focused on the individual level, as we believed that the final outcomes of irrigation institutions could be assessed.

The first part of this dissertation, which is designated to the description of the water sector's institutional environment in Tunisia, shows that serious shortage problems can occur in the near future if water demand continues to grow like it is currently. In fact, despite the creation and implementation of many institutions oriented towards irrigation demand management, the demand for irrigation has continued to increase over the past three decades. This was mainly due to the creation of new irrigated areas and to the intensification of the existing ones. Also, at this institutional level, feedback from governance structures (Water Users' Associations: WUA) on the institutional environment was not recorded in the institutional scheme of Tunisian water sector. This feedback is considered as pressure executed in order to achieve some adjustments at the constitutional level, favouring the organizations operating at the governance level. This gives the impression that the WUA in Tunisia can be defined as micro-institutions rather than users' associations. At the governance level, a comparative efficiency analysis of WUAs sample shows that still some inefficiency related to their functioning occurs. Additional savings 
in financial resources (spent by these associations) are possible and can be used for other local irrigation development purposes. These savings could for instance be reflected in the irrigation water price and the cost recovery levels. Also, low WUA performance could have a negative effect on farmers' perceptions, attitudes, and decision making. This effect was the purpose of the investigation into further applications undertaken at the individual level.

At the individual level, we confirm that significant relationship exists between the quality of the local irrigation governance and the irrigation water use efficiency (IWUE) at the farm level. We also found that current irrigation pricing policies can have different impacts on farmers, according to their farming efficiency levels. More efficient farmers have more inelastic water demand functions. Thus, the Tunisian pricing policy aiming to enhance the technical efficiency of farmers in addition to charging higher irrigation rates, could fail in generating additional water savings at the national level. Moreover, the study of the efficiency of current irrigation usage rights in Tunisia shows that additional economic gains could be collected from farmers if various attributes of the rights could be improved. More precisely, we found that farmers are willing to pay higher water prices for more reliable and for transferable irrigation rights.

It is then clear according to this work that water institutions are important elements affecting the performances of the water sector, both at macro and micro levels. Improvements of their functioning and performances have deep effects on social as well as individual welfare. A performing irrigation institution will be the one which generates a "good local irrigation governance" context providing motivation and incitation for individual irrigators. 